\title{
CORRESPONDENCE
}

Marking resection margins in surgical biopsy specimens

We were interested to read the recent papers and correspondence in the Journal concerning the marking of resection margins in surgical biopsy specimens, using artists pigments suspended in acetone, ${ }^{1}$ Tipp-Ex fluid, ${ }^{2}$ organically coloured gelatins ${ }^{3}$ and alcian blue. ${ }^{+}$

The traditional method using India ink is not particularly satisfactory due to the prolonged period of drying required and the tendency for the ink to spread. We have overcome this problem by applying Bouin's solution to the specimen immediately after painting on the ink, either by immersion or using a syringe. The ink seems to become instantaneously "fixed" to the specimen, and the cutting up of the specimen can proceed without delay. The ink remains firmly adherent to formalin fixed or fresh tissue throughout processing and is clearly seen in

histological sections (figure). The ink also firmly adheres to any tissue retained in formalin for further examination.

$$
\begin{array}{r}
\text { AD BULL } \\
\text { RD START } \\
\text { JHF SMITH } \\
\text { Department of Histopathology, } \\
\text { Northern General Hospital, } \\
\text { Herries Road, } \\
\text { Sheffield S5 } 7 A U
\end{array}
$$

1 Paterson DA, Davies JD. Marking planes of surgical excision on breast biopsy specimens: use of artists' pigments suspended in acetone. J Clin Pathol 1988;41:1013-6.

2 Harris MD. Tipp-Ex fluid: A convenient marker for surgical resection margins. J Clin marker for surgical
Pathol 1990;43:346.

3 Armstrong JS, Weinzwieg IP, Davies JD. Differential marking of excision planes in screened breast lesions by organically coloured gelatins. J Clin Pathol 1990;43: 604-7.

4 Birch PJ, Jeffrey MJ, Andrews MIJ. Alcian blue: reliable rapid method for marking resection margins. J Clin Pathol 1990;43:608.

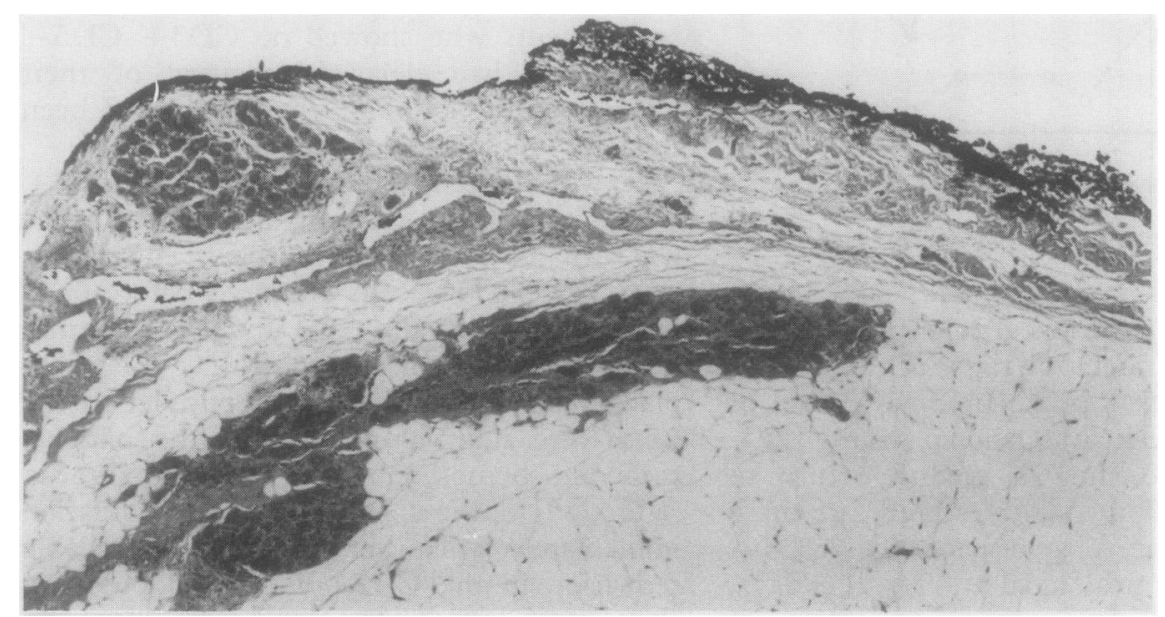

Breast biopsy specimen showing resection margin marked with India ink following immersion in Bouin's solution.

\section{Use of Tipp-Ex fluid as a marker of surgical resection margins}

I feel I must respond to Clarke and Sarsfield's criticism of the use of Tipp-Ex fluid as a marker of surgical resection margins. ${ }^{1}$ In my original submission ${ }^{2}$ I stated that the processing equipment was unaffected. This statement was in response to a point raised by the referee and was intended to refer specifically to the machine processing. Far from my being "economical with the truth", I think that the critics are being excessively pedantic in extending this to include microtome knife blades. Laboratory staff were consulted before the letter was submitted and all felt that as many now use disposable blades, which can easily be moved to a fresh area after cutting, this was of no great importance.

Tipp-Ex is now being used by other histopathology laboratories which feel that the speed with which it can be used and the lack of "mess" associated with other methods far outweigh any problems in cutting. I hope that criticisms such as this will not dissuade others from trying this convenient technique in their own laboratories.

\section{HARRIS} Add of Histopathology, Cambridge

1 Clarke TJ, Sarsfield P. Use of Tipp-Ex for surgical resection margins. J Clin Pathol 1990; 43:879.

2 Harris MD. Tipp-Ex fluids convenient marker for surgical resection margins. J Clin Pathol 1990;43:346

T cell receptor (TCR) gene rearrangements in the assignment of tumour cell lineage

Hodges et al studied DNA from peripheral T cell lymphoma (T-NHL) and failed to show the clonal gene rearrangement of TCR $\beta$ or $\gamma$ chain genes in five of six cases.' These data are surprising and contrast with previous work that has shown clonal TCR $\beta$ gene rearrangement to be present in more than $95 \%$ cases of T-NHL ${ }^{2-4}$

The occurrence of T-NHL without clonal rearrangement of the TCR $\beta$ or $\gamma$ genes implies that $\mathrm{T}$ cell leukaemias with a similar genetic make-up exist, but although four such T leukaemias have been described, these were all lymphoblastic with features of maturation arrest at the prethymic stage (CD7 and CD5 positive, but negative for other $\mathrm{T}$ cell markers including CD3). ${ }^{56}$ Because peripheral $T$ NHL do not result from a clonal expansion of prethymic $T$ cells, these cases are not comparable.

The most plausible explanation for the inability to detect clonal TCR gene rearrangement in "T-NHL" is that the histological diagnosis was incorrect. ${ }^{2}$ It would therefore be helpful to know whether these cases had been the subject of formal histological review; if so, by which histopathologist, and what criteria were used to establish the diagnosis of T-NHL? If formal review was not carried out then the conclusions reached are highly suspect.

N O'CONNOR Department of Haematology Royal Shrewsbury Hospital, Shrewsbury $S Y 38 B R$

1 Hodges E, Stacey GN, Howell WM, Jones DB, Smith JL. Clonality of $T$ cell and phenotypically undefined lymphoid neoplasms: the value of genotypic analysis. J Clin Patho 1990;43:548-53.

2 O'Connor NTJ. Genotypic analysis of lymph node biopsies. J Pathol 1987;151:185-90.

3 Griesser H, Feller A, Lennert K, Minden M, Mak TW. Rearrangement of the beta chain of the $T$ cell antigen receptor and immunoglobulin genes in lymphoproliferative disglobulin genes in lymphoproliferative
orders. J Clin Invest 1986;78:1179-84.

4 Knowles DM, Pellici P-G, Dalla-Favera R. Tcell receptor beta chain gene rearrangements: genetic markers of $\mathrm{T}$-cell lineage and clonality. Hum Pathol 1986;17:546-51.

5 Foroni L, Laffan M, Boehm T, Rabbitts TH Catovsky D, Lussatto L. Rearrangement of the $T$-cell receptor delta genes in human $T$ cell leukemias. Blood 1989;73:559-65.

6 Dyer MJS. T-cell receptor delta/gamma rearrangements in lymphoid neoplasms. Blood 1989;74:1073-83.

Dr Smith comments

In his letter Dr O'Connor makes the point that the cases we studied may not be of $T$ cell histology. All the cases included in our paper were reviewed by Professor Dennis Wright, University of Southampton, and furthermore, cases were immunostained with a panel of monoclonal antibodies. The cases were selected on the basis of histology and $T$ cell immunophenotype. While it is acknowledged that this is a particularly difficult area in histopathology, we do not feel these results are suspect; rather that they represent a growing number of lymphomas of peripheral $\mathrm{T}$ cell lymphoma histology that do not have clonal TcR gene rearrangement. ${ }^{12}$ We should be pleased to learn of the experiences of others in this particular field.

1 Smith JL, Haegert DG, Hodges E, et al. Phenotypic and genotypic heterogeneity of peripheral T cell lymphoma. Br J Cancer 1988, 58:723-9.

Weiss LM, Picker LJ, Grogan TM, Warnke RA, Sklar J. Absence of clonal $\beta$ and $\gamma \mathrm{T}$ cell receptor gene rearrangements in a subset of peripheral T cell lymphomas. Am J Patho 1988;130:436-42. 